\title{
Megalitik Di Situbondo Dan Pengaruh Hindu Di Jawa Timur
}

\section{Bagyo Prasetyo}

Keywords: culture, tradition, chronology, hindu, megalithic, continuity

\section{How to Cite:}

Prasetyo, B. (1999). Megalitik Di Situbondo Dan Pengaruh Hindu Di Jawa Timur. Berkala Arkeologi, 19(2), 22-29. https://doi.org/10.30883/jba.v19i2.820

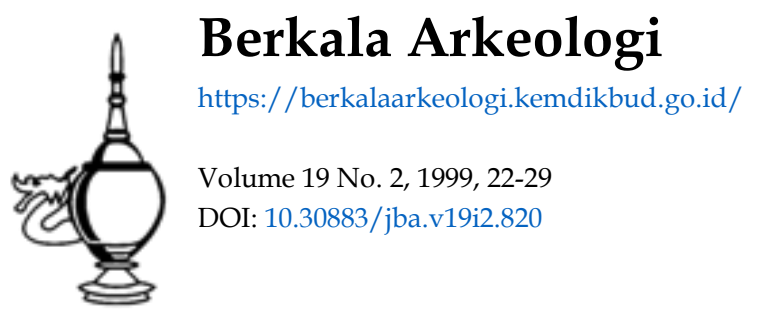

\section{(c) (i) (5)}

This work is licensed under a Creative Commons Attribution-NonCommercial-ShareAlike 4.0 International License. 


\title{
MEGALITIK DI SITUBONDO DAN PENGARUH HINDU DI JAWA TIMUR
}

\author{
Bagyo Prasetyo \\ (Pusat Penelitian Arkeologi Nasional)
}

\section{A. Pendahuluan}

Situbondo secara administratif merupakan daerah tingkat II yang ada di Jawa Timur, yang berbatasan dengan Kabupaten Bondowoso dan Banyuwangi yang ada di sebelah selatannya, sebelah barat berbatasan dengan Kabupaten Probolinggo, sebelah utara merupakan Selat Madura dan di sebelah timur merupakan selat Bali. Wilayah Situbondo terdiri dari 17 wilayah kecamatan dan 4 wilayah perwakilan kecamatan.

Secara geografis Situbondo terletak di kawasan timur Pulau Jawa, yang berdekatan dengan Pulau Bali dengan posisi antara $7^{\circ} 35^{\prime}-7^{\circ} 44^{\prime}$ Lintang Selatan dan 113 $30^{\prime}$ $114^{\circ} 42^{\prime}$ Bujur Timur. Luas wilayah ini adalah 163.850 hektar, dengan bentuk memanjang dari barat ke timur lebih kurang 140 kilometer, dengan lebar wilayah lebih kurang 11 kilometer (BPS dan Bappeda Kabupaten Situbondo 1998). Wilayah Situbondo mempunyai topografi yang dipengaruhi oleh keadaan bentang alam berupa laut dan pegunungan. Dari kedua bentang alam tersebut, pengaruh yang paling besar adalah adanya daerah pegunungan, sehingga wilayah ini dikelompokkan ke dalam tipe daerah yang didominasi oleh perbukitan dan pegunungan. Daerah perbukitan dan pegunungan mendominasi sekitar $60 \%$ dari keseluruhan luas wilayah Situbondo, sedangkan sisanya merupakan daerah dataran pantai (Setjen Biro Data dan Analisa 1981). Sehubungan dengan tipe topografi yang berbeda, maka wilayah Situbondo mempunyai kisaran ketinggian antara $0-1250 \mathrm{~m}$ di atas permukaan laut.

Pengamatan terhadap jenis batuan di wilayah ini menunjukkan adanya sejumlah jenis batuan sedimen maupun batuan vulkanik. Hal ini disebabkan bahwa wilayah Situbondo merupakan formasi batuan gunung api hasil erupsi Gunung Ringgit dan Gunung Argopuro. Formasi yang berasal dari Gunung Ringgit mengandung lava, breksi gunung api, batupasir tufan, tuf, basal, basal leusit, andesit piroksin dan andesit hornblend. Formasi lainnya adalah yang berasal dari Gunung Argopuro yang mengandung lava, breksi gunung api, tuf, basal dan andesit. Mengenai formasi batuan sedimen di daerah ini adalah Formasi Menuran yang mengandung napal, batu pasir gamping dengan sisipan tuf. Formasi ini merupakan batuan tertua yang tersingkap di daerah ini (Pendowo 1991).

Keberadaan aneka batuan ini sangat mendukung adanya kehadiran budaya materi khususnya peninggalan megalitik yang banyak ditemukan di wilayah Situbondo. Hal ini didasarkan pada hasil penelitian survei Bidang Prasejarah Pusat Penelitian 
Arkeologi Nasional yang telah menjangkau seluruh wilayah di Situbondo, dan dari hasil penelitian telah diperoleh data untuk sementara sebanyak 15 buah situs yang mengandung corak budaya megalitik.

\section{B. Budaya Megalitik}

Gambaran adanya kehadiran budaya megalitik di wilayah Siubondo sampai saat ini baru memberikan informasi adanya tinggalan-tinggalan megalitik di 8 wilayah kecamatan dengan 14 desa. Adapun lokasinya dapat ditunjukkan pada tabel di bawah ini:

Tabel : Data lokasi yang mengandung temuan megalitik

\begin{tabular}{|c|l|l|l|}
\hline No & \multicolumn{1}{|c|}{ Kecamatan } & \multicolumn{1}{c|}{ Desa } & \multicolumn{1}{c|}{ Dusun } \\
\hline 1 & Banyuglugur & Selobanteng & Beringin \\
\hline 2 & Besuki & Sumber Rejo & Ngabinan Barat \\
\hline \multirow{3}{*}{3} & \multirow{3}{*}{ Sumbermalang } & Pelalangan & Winong \\
\cline { 3 - 4 } & & Tamansari & Tamansari \\
\cline { 3 - 4 } & & Tlogosari & Locare Timur \\
\hline 4 & \multirow{2}{*}{ Suboh } & Dawuan & Dakon \\
\cline { 3 - 4 } & & Suboh & Karangsukun \\
\hline 5 & \multirow{2}{*}{ Bungatan } & Lamparan & Polai Kemirian \\
\cline { 3 - 4 } & & Patemon & Gebangan \\
\cline { 3 - 4 } & & & Krajan Dua \\
\hline 6 & \multirow{2}{*}{ Kendit } & Kukusan & Krajan Timur \\
\cline { 3 - 4 } & & Tambak Ukir & Tambak Ukir \\
\cline { 3 - 4 } & & Klatakan & Krajan \\
\hline 7 & Banyuputih & Sumberrejo & Lesung \\
\hline 8 & Arjasa & Bayeman & Krajan \\
\hline
\end{tabular}

Hasil survei yang dilakukan oleh penulis terhadap situs-situs megalitik di wilayah Situbondo pada tahun 1999 menunjukkan adanya sejumlah karakter budaya yang mempunyai bentuk-bentuk yang sama dengan peninggalan megalitik di wilayah Bondowoso maupun Jember. Adapun data megalitik yang dapat diperoleh menunjukkan bentuk-bentuk sarkofagus, bangunan berundak, lumpang batu dan menhir.

\section{Sarkofagus}

Bentuk sarkofagus di wilayah Situbondo seperti umumnya ditemukan di tempattempat lain terutama di Jember maupun Bondowoso yang mempunyai wilayah budaya sama, yaitu tutup dan wadah yang sebangun dengan mempunyai rongga pada bagian 
dalamnya. Demikian juga dengan fungsinya, yang pada umumnya digunakan sebagai tempat menyimpan mayat. Sarkofagus umumnya berbentuk menyerupai gendang dengan beberapa variasi.

a. variasi 1 berupa wadah dan tutup sebangun dengan rongga bagian tutup lebih dangkal. Pada masing-masing sisinya membentuk sudut pangkasan yang cukup tajam sehingga membentuk suatu bidang samping. Pada salah satu sisinya terdapat tonjolan. Bangunan seperti ini hanya ditemukan 2 buah di Situs Pelalangan (Sumbermalang) dan Situs Tlogosari (Sumbermalang).

b. variasi 2 berupa wadah dan tutup sebangun dengan rongga bagian tutup lebih dangkal. Pada masing-masing sisinya membentuk sudut pangkasan yang cukup tajam sehingga mempunyai suatu bidang samping. Bangunan tipe ini terdapat sejumlah 1 buah di Situs Krajan Timur (Kendit), 2 buah di Situs Tambakukir (Kendit), 1 buah di Situs Tlogosari (Sumbermalang), 5 buah di Situs Lamparan (Bungatan), dan 1 buah di situs Ngabinan (Besuki).

c. variasi 3 berupa wadah dan tutup sebangun dengan rongga bagian tutup lebih dangkal. Pada masing-masing sisinya tidak menunjukkan adanya suatu sudut pangkasan yang tajam, sehingga seolah-olah merupakan suatu lengkungan yang mengarah ke masing-masing sisinya. Tingkat pengerjaan sederhana tanpa adanya penggosokan pada bagian permukaan batunya. Tipe semacam ini ditemukan sebanyak 1 buah di Situs Tlogosari (Sumbermalang), 1 buah di Situs Krajan Timur (Kendit), 2 buah di Tambakukir (Kendit), 2 buah di Krajan (Kendit), 3 buah di Lamparan (Bungatan), 1 buah di Krajan Dua (Bungatan), dan 1 buah di Ngabinan (Besuki).

d. variasi 4 berupa wadah dengan rongga yang dalam. Wadah ini tidak dibuat sebagai mana lazimnya, namun dikerjakan melalui pemahatan dan penggosokan yang cukup halus serta dibentuk menyerupai seekor banteng dalam posisi sedang duduk, dengan salah satu sisi badannya dihias dengan relief pola sulur-suluran serta inskripsi berangka tahun. Bangunan ini hanya ditemukan di Situs Selobanteng Kecamatan Banyuglugur.

\section{Bangunan berundak}

Terdapat dua jenis bangunan berundak di wilayah Situbondo, yang kedua-duanya masuk dalam wilayah Kecamatan Sumbermalang. Bangunan berundak pertama terletak di puncak Gunung Argopuro, yang disusun oleh beberapa undakan. Bangunan berundak di Gunung Argopuro ini sudah dibahas dan dan disinggung sedikit dalam tulisan Kohlbrugge dan Stutterheim.

Bangunan berundak kedua terletak di Situs Pelalangan, yang terdiri atas dua buah monolit yang dipahat dalam bentuk undakan. Secara keseluruhan undakan ini mempunyai orientasi timur-barat dan terletak di tepi jalan desa antara Sumbermalang menuju Besuki. Monolit pertama berbentuk agak membulat dengan ukuran diameter 
sekitar 4,4 meter dan tinggi 2,7 meter. Bagian atas dari monolit tersebut dipahat dalam bentuk 7 buah undakan, dengan ukuran masing-masing undakan sekitar: panjang 22 $\mathrm{cm}$, lebar $65 \mathrm{~cm}$ dan tinggi $14 \mathrm{~cm}$. Pada bagian kanan dan kiri undakan terdapat lengan tangga yang dibentuk bertingkat-tigkat sejajar dengan setiap anak tangga. Monolit kedua terletak sekitar 5 meter di sebelah barat monolit pertama, secara umum bentuknya adalah empat persegi dengan variasi membesar pada bagian atasnya. Antara monolit pertama dan monolit kedua dihubungkan oleh halaman dari tanah. Ukuran monolit adalah panjang 7,5 meter, lebar atas 4 meter, lebar bawah 2 meter dan tinggi 4 meter. Dibandingkan dengan monolit pertama, tampaknya mempunyai bentuk yang lebih ramping dan lebih tinggi. Sama seperti monolit pertama, pada permukaan atas monolit kedua ini juga dipahatkan sebanyak 11 buah undakan dengan lengan tangga di sebelah kanan dan kirinya. Undakan ini mempunyai ukuran panjang $35 \mathrm{~cm}$, lebar $75 \mathrm{~cm}$ dan tinggi $20 \mathrm{~cm}$.

Berdasarkan ceritera rakyat, bangunan berundak ini mempunyai kaitan erat dengan bangunan berundak di Gunung Argopuro. Bangunan berundak ini dianggap sebagai benteng pertahanan Raja Bagdad dalam menyusun kekuatan sewaktu akan melamar putri Rengganis di Argopuro.

\section{Menhir}

Seperti lazimnya bentuk menhir lainya, menhir di wilayah Situbondo tidak mempunyai ciri khusus dari bentuk variasi tipologisnya. Umumnya berbentuk tidak beraturan dan tidak dikerjakan. Tidak begitu banyak jumlah kehadiran menhir di wilayah ini, dan tampaknya lebih berkonsentrasi di Situs Tamansari (Kecamatan Sumbermalang). Melalui pengamatan dari permukaan, belum dapat dipastikan fungsi menhir di situs ini, tentunya penelitian secara vertikal melalui ekskavasi akan lebih memperjelas peranan menhir tersebut. Pengukuran terhadap menhir-menhir yang ada memberikan gambaran berupa kisaran tinggi antara $19-74 \mathrm{~cm}$, lebar $14-23 \mathrm{~cm}$, dan tebal antara $12-21 \mathrm{~cm}$.

\section{Lumpang batu}

Secara umum lumpang batu adalah piranti yang dipakai untuk menumbuk biji-bijian. Menurut persebarannya, jenis benda ini ditemukan di Kecamatan Banyuputih dan Kecamatan Arjasa, dengan berbagai variasinya.

a. variasi 1: bentuk penampang atas membundar dengan permukaan cekung dan melandai ke arah lubang, tingkat pengerjaan sederhana. Tipe ini ditemukan di Situs Lesung (Banyuputih) dengan kisaran ukuran garis tengah 68, tinggi $24 \mathrm{~cm}$ dan diameter lubang $20 \mathrm{~cm}$.

b. variasi 2: bentuk penampang atas membundar dengan permukaan rata serta terdapat pelipit di pinggirannya, bagian atas lebih lebar dibandingkan dengan 
bagian bawah, dengan tingkat pengerjaan cukup intensif. Tipe ini ditemukan sebanyak 2 buah di Situs Lesung (Banyuputih) dengan kisaran ukuran garis tengah penampang atas 70-78 cm, garis tengah penampang bawah $38-52 \mathrm{~cm}$, tinggi $38-60$ $\mathrm{cm}$ dan diameter lubang $22-23 \mathrm{~cm}$.

c. variasi 3 : bentuk penampang atas membundar dengan permukaan rata serta tidak ada pelipit di pinggirannya, bagian atas lebih lebar dibandingkan dengan bagian bawah tingkat pengerjaan cukup intensif, selain lubang untuk tempat biji-bijian yang akan ditumbuk, terdapat pula lubang kecil yang dangkal yang kemungkinan untuk tempat meletakkan sementara biji-bijian yang sudah ditumbuk. Tipe ini ditemukan di Situs Lesung (Banyuputih) dan Karangsukun (Suboh), dengan kisaran ukuran diameter atas 70-90 cm, diameter bawah $33-66 \mathrm{~cm}$, tinggi $35-50 \mathrm{~cm}$ dan diameter lubang 15-17 cm.

d. Bentuk penampang atas membundar, tidak ada pengerjaan terhadap bentuk lumpang kecuali hanya pada bagian lubangnya saja. Tipe ini ditemukan di Situs Lesung (Banyuputih) dengan ukuran diameter $80 \mathrm{~cm}$, tinggi $42 \mathrm{~cm}$ dan diameter lubang $15 \mathrm{~cm}$.

e. Bentuk penampang atas membundar dengan permukaan rata tanpa pelipit, bagian atas lebih lebar daripada bagian bawah dan pada bagian pinggangnya juga terdapat pengecilan bentuk. Tipe ini ditemukan 2 buah di Situs Krajan (Arjasa) dengan ukuran kisaran diameter atas $72 \mathrm{~cm}$, diameter bawah $38-48 \mathrm{~cm}$, tinggi $28-32 \mathrm{~cm}$, dan diameter lubang $17-18 \mathrm{~cm}$

\section{Kronologi Perkembangan Budaya Megalitik Situbondo}

Hadirnya budaya megalitik khususnya di wilayah Situbondo banyak mendapat pertentangan dari para ahli tentang kronologi perkembangannya. Khusus mengenai peninggalan megalitik berupa punden berundak yang ditemukan di Gunung Argopuro yang sudah banyak dimuat dalam berbagai buku, dan ada beberapa ahli yang mencoba untuk mengemukakan pendapatnya. Kohlbrugge sebagai orang pertama yang menyatakan bahwa bangunan berundak di Gunung Argopuro mempunyai karakter hindu, dan menganggap tempat tersebut digunakan sebagai kuil untuk pemujaan Dewa Siwa (Geldern 1945). Berbeda dengan Stutterheim yang menyanggah pendapat Kohlbrugge, yang lebih menekankan bahwa bangunan berundak Gunung Argopuro berasal dari masa pra-Hindu. Hal ini dikemukakan setelah membandingkan dengan bangunan ahu dan marae dari wilayah Polinesia.

Lepas dari pertentangan pendapat tersebut di atas, maka hasil test-pit (gali uji) sebanyak 3 lubang di sekitar temuan lumpang batu di situs Krajan, Bayeman telah ditemukan sejumlah artefak berupa tembikar maupun keramik serta sisa pembakaran. Berdasarkan analisis pertanggalan karbon yang dilakukan di laboratorium P3G Bandung menunjukkan hasil pertanggalan 1.250 $\pm 240 \mathrm{BP}$ atau sekitar $1000-1500$ 
tahun Sebelum Sekarang (sekitar Abad 5 - 10 Masehi). Selain data kronologi yang didasarkan pada pertanggalan karbon, tampaknya diperkuat pula oleh adanya inskripsi berbentuk angka tarikh yang terpahatkan pada dinding wadah sarkofagus yang berbentuk seekor sapi yang tertulis 1324 Saka (1402 Masehi). Inskripsi ini menggunakan aksara Jawa Kuno dengan jenis huruf kuadrat, yang dicirikan oleh huruf-huruf yang timbul.

Data pertanggalan ini sebetulnya masih terlalu minim mengingat luasnya sebaran situs megalitik di wilayah Situbondo, sehingga belum dapat mewakili kronologi perkembangan budaya megalitik di sini. Hal ini disebabkan oleh masih sedikitnya data sisa pembakaran yang diperoleh sebagai bahan dalam menentukan pertanggalan secara absolut. Sebagai bahan perbandingan beberapa ekskavasi yang telah dilakukan terhadap situs megalitik wilayah Bondowoso dan Jember yang merupakan wilayah tetangga serta dianggap mempunyai suatu kesatuan budaya yang sama, sementara ini belum dapat memberikan hasil pertanggalan yang cukup memuaskan. Terkecuali hasil sisa pembakaran yang memberikan titik terang terhadap pertanggalan di Situs Doplang khususnya dan mewakili situs megalitik di wilayah Jember pada umumnya, yaitu menunjukkan sekitar abad 13-15 Masehi (hasil C14 dari P3G Bandung memberikan angka $580 \pm 100$ BP) lebih muda dibandingkan dengan hasil pertanggalan situs Krajan, Bayeman, namun mempunyai kisaran waktu yang sama dengan inskripsi pada wadah sarkofagus di Situs Selobanteng.

\section{Pengaruh Hindu di Jawa Timur}

Sejak runtuhnya Kerajaan Mataram Kuno di Jawa Tengah yang mengalami kehancuran karena letusan Gunung Merapi yang maha dahsyat, maka sesuai dengan landasan kosmogonis kerajaan-kerajaan kuno perlu dibangun kerajaan baru dengan wangsa yang baru pula. Muncullah kemudian cikal bakal wangsa Isana yang didirikan oleh Pu Sindok serta kerajaan baru di Jawa Timur yang tetap diberi nama Mataram, sesuai dengan yang tertuang pada Prasasti Paradah tahun 865 Ç (943 M) dan Prasasti Añjukladang tahun 859 Ç (937 M) (Brandes 1913). Pu Sindok sebagai pendiri wangsa Isana sekurang-kurangnya telah memerintah sejak tahun 929-948 M (Sumadio 1984).

Istilah wangsa Isana terdapat di dalam Prasasti Pucangan yang dikeluarkan oleh Raja Airlangga pada tahun $963 \mathrm{C} \mathrm{(1041} \mathrm{M),} \mathrm{yang} \mathrm{memuat} \mathrm{tentang} \mathrm{penghormatan} \mathrm{kepada}$ Brahma, Wisnu dan Siwa yang disusul dengan penghormatan kepada Raja Airlangga. Selanjutnya dimuat silsilah Raja Airlangga, mulai dari Sri Isanatungga atau Pu Sindok. Sri Isana mempunyai anak perempuan yang kawin dengan Sri Lokapala dan kemudian mempunyai anak bernama Sri Makutawangsawarddhana, yang disebut sebagai keturunan wangsa Isana (Kern 1917). 
Berdasarkan data tersebut di atas terlihat bahwa sekurang-kurangnya sekitar abad 9 10 Masehi wilayah Jawa Timur telah mendapat pengaruh dari agama Hindu. Sejak tampuk pemerintahan dipegang $\mathrm{Pu}$ Sindok dan terus bergulir melalui pergantian tampuk pimpinan mulai dari Tguh Darmawangsa (dianggap sebagai penjelmaan Wisnu), terus berlanjut ke Airlangga hingga berakhirnya kekuasaan wangsa Isana yaang telah memerintah selama tiga abad setelah ditaklukannya Kadiri/Daha oleh Ken Arok/Rajasa dari Tumapel pada tahun 1222 M yang disebutkan dalam kitab Nagarakertagama. Peristiwa ini kemudian disusul dengan timbulnya kerajaan baru yaitu Singhasari/Majapahit dengan penguasanya raja-raja dari wangsa Rajasa sampai kemudian runtuhnya kerajaan Majapahit pada sekitar akhir abad 15 Masehi karena serangan kerajaan Islam Demak. Fakta ini juga didasarkan pada pemberitaan Pigafetta dan Duarte barbosa yang dapat disimpulkan bahwa sekitar tahun 1518 dan 1521 telah terjadi pergeseran politik di Majapahit yaitu berupa pengalihan penguasaan dari tangan penguasa Hindu ke tangan penguasa Islam di Demak.

\section{E. Kesimpulan}

Menyimak kronologi perkembangan budaya megalitik di Situbondo terlihat bahwa paling tidak pada sekitar abad 5 (sesuai dengan pertanggalan karbon) bahkan ada kemungkinan jauh sebelumnya, bahwa tradisi megalitik telah mengakar dan terus berkembang jauh kemudian sampai abad ke $15 \mathrm{M}$ atau mungkin lebih setelah runtuhnya kerajaan dengan ciri Hindu (Majapahit) di wilayah Jawa Timur.

Megalitik sebagai suatu tradisi dan kepercayaan asli bangsa Indonesia tampaknya tidak mudah digeser oleh pengaruh agama dari luar (asing). Pada umumnya pengaruh agama asing hanya melekat pada masyarakat dalam lingkungan istana atau masyarakat yang termasuk dalam jangkauan tampuk pemerintahan, sedangkan bagi masyarakat yang ada di luar tidak terpengaruh oleh unsur-unsur tersebut. Kalau diperhatikan secara seksama tampaknya masyarakat pendukung tradisi megalitik selalu membangun komunitas yang cukup luas. Walaupun pengaruh Hindu cukup kuat di Jawa Timur yang memakan waktu 5 dekade sejak abad 10 sampai 15 Masehi, tampaknya hal tersebut tidak mempengaruh komunitas masyarakat tradisi megalitik. Banyak muncul kantong-kantong komunitas yang tersebar luas di wilayah Jawa Timur sejak daerah Situbondo, Jember, Bondowoso, Bojonegoro serta beberapa daerah lainnya yang bukan merupakan pusat-pusat kerajaan Hindu. Ditemukannya sejumlah besar jenis-jenis keramik yang cukup representatif serta sejumlah manik-manik berciri Pasifik serta perkakas-perkakas yang digunakan sebagai bekal kubur megalit memberikan indikasi bahwa pedukungnya merupakan masyarakat yang dinamis serta bukan masyarakat dari kalangan bawah. 


\section{KEPUSTAKAAN}

Bagyo Prasetyo dan Retno Handini, 1999. Survei Keruangan Situs-situs Megalitik di Kabupaten Situbondo, Provinsi Jawa Timur, dalam Laporan Penelitian Arkeologi Bidang Prasejarah Tahun 1999. Jakarta: Puslit Arkenas, belum terbit.

Badan Pusat Statistik dan Bappeda Kabupaten Situbondo, 1998. Situbondo dalam Angka 1998. Situbondo: Badan Pusat Statistik Situbondo.

Brandes, J.L.A. 1913. Oud Javaansche Oorkonde, Nagelaten transcripties van wijlen Dr. J.L. Brandes, uitgegeven door N.J. Krom, VBG LX.

Geldern, Robert von Heine, 1945. Prehistoric Research in the Netherlands Indies, dalam Ppeter Honig dan Frans Verdoorn (ed), Science and Scientist in the Netherlands Indies. New York: Board for Netherlands Indies, Surinam anc Curacao.

Kern, H., 1917. De steen van den berg Penanggungan (Surabaya), thans in 't Indian Museum te Calcutta, dalam Verspreide Geschriften VII. 's-Gravenhage: Martinus Nijhoff.

Knebel, J., 1906. Beschrijving der Hindoe-Oudheden in de afdeelingen Djember, Banjoewangi, Bandawasa, Sitoebanda, en Besoeki der Residentie Besoeki, dalam ROC 1904, Batavia: Albrecht \& Co. Hlm. 135-156.

Pendowo, Budisantoso, 1991. Geologi Lembar Besuki Jawa Timur. Bandung: Pusat Penelitian dan Pengembangan Geologi Departemen Pertambangan dan Energi, Direktorat Jendral Geologi dan Sumberdaya Mineral.

Sekretariat Jendral Biro Data dan Analisa, 1981. Potensi dan Sarana Penunjang Pengembangan Industri Propinsi Jawa Timur. Jakarta: Departemen Perindustrian.

Sumadio, Bambang (ed.),1984. Sejarah Nasional Indonesia II. Jakarta: Balai Pustaka. 